\title{
PERSECUTION AND LONGING OF YEMENITE JEWS IN THE HANDSOME JEW
}

\author{
Ebrahim Mohammed Alwuraafi
}

Al-Baha University

\begin{abstract}
The article is an attempt to highlight the suffering of the Yemenite Jews as depicted in Ali Al-Muqri's The Handsome Jew. It argues that Ali Al-Muqri has been able to articulate the suffering experienced by Yemenite Jews for thousands of years and that the novel presents a fair and realistic picture of the Jewish society during a crucial period in the history of Yemenite Jews. In addition, the article examines how and why Yemenite Jews actively took on diasporic consciousness. It argues that this feeling of unbelonging and longing needs to be contextualized according to their specific living conditions in Yemen. It also argues that Jewish excitement during the messianic activity, their longing for Zion, and their dream of return are the outcomes of persecution and discrimination that they received at the hands Zaydi rulers of Yemen.
\end{abstract}

Keywords: Yemen, Jews, persecution, longing, Zaydi

DOI: https//doi.org/10.3176/tr.2021.1.04

Received 29 April 2020, accepted 3 June 2020, printed and available online 10 March 2021

\section{Introduction}

Ali Al-Muqri, born in 1966 in Taiz, is a Yemeni novelist and writer. He began writing at the age of eighteen. Al-Muqri has published four novels: Black Taste, Black Odour 1 (2008), The Handsome Jew ${ }^{2}$ (2009), Hurma (Woman) (2012) and Adeni Incense (2014). He has published a number of poetic works including $A$ Window into

1 The novel was longlisted for the International Prize for Arabic Fiction in 2009.

2 The novel was longlisted for the International Prize for Arabic Fiction in 2011. 
the Body (1987), Restorations (1999), and It Comes with Forgetfulness (2003). AlMuqri is a daring and controversial writer. He always indulges in themes which are considered as taboos in the Arab world. Hence, some of his poetic collections have been banned in North Yemen for being too erotic. After the unification of North Yemen with South Yemen in 1990, Ali Al-Muqri gained reputation as a cultural editor of many progressive and oppositional publications.

Al-Muqri is the novelist of the marginalized. His first novel Black Taste, Black Odour raises the question of black people in Yemen and how they are marginalized by successive regimes. His second novel The Handsome Jew deals with the suffering of Jews in Yemen particularly under the Zaydi regime. His third novel Hurma (Woman) deals with the Yemeni woman who is silenced, oppressed and marginalized by her male counterpart. This has been acknowledged by Al-Muqri himself, who says that in his two novels, The Handsome Jew and Black Taste, Black Odour he "discusses two Yemeni communities, the Jews and the Blacks, who have been marginalized in the Yemeni society for sectarian, ethnic and/or religious reasons" (as cited in Al-Ameri 2011, para. 3). He believes that this marginalization most of the time "stems from linking religion with the concept of the homeland" (as cited in Al-Ameri 2011, para. $3)$. Regarding their belonging to the Yemeni society in general, Al-Muqri believes that "the society marginalized this group [the Jews], even though they are Yemenites because the society in Yemen is still adhering to race, ethnicity and genealogy" (as cited in Al-Ameri 2011, para. 6).

The Handsome Jew deals with the dilemma of Yemenite Jews. The significance of the novel lies in its accurate and straightforward expression of the historic condition of the Jews in Yemen. The novel narrates the suffering of Jews during the Zaydi regime, which is unprecedented within the continuum of Jewish historical experience in the region and explicitly reveals the racial and anti-Semitic motivation of the sadist Zaydis to annihilate all Jews who were part and parcel of the Yemeni community. Besides brutal deaths and brutally imposed conversions, there was a brutally imposed life of humiliation, deprivation and degradation.

Due to the Palestinian-Israeli conflict, writing fiction about Jews in the Arab world unvaryingly provokes controversy by inspiring acclaim and repulsion in equal measure. Some readers and critics see such fiction as a call on the part of these writers to normalize with the Israelis/Jews who are well-known for their hostility to Islam and Muslims throughout the ages. Others see such writings as something normal as they do not deal with Israelis but with Arab Jews who have been part and parcel of the Arab community since antiquity. Al-Muqri's novel is not different; the novel sparked a fierce debate about its premise, the deliberate suppression and oppression of the Yemenite Jews for centuries as well as about the nature and purpose of its representation of Jews. Readers and critics have had polarized opinions about the novel in representing the Yemenite Jews. On the one hand, it is greeted with outrage as it tries to tell the story of and humanize the enemy. On the other hand, the novel is praised for resurrecting the past of one of the most forgotten communities of Yemen that once established one of the greatest kingdoms in the Arab Peninsula and for its call for tolerance and coexistence irrespective of race, religion, or ethnicity. 


\section{Historical context}

There are numerous traditions and accounts concerning the origin of Jews in Yemen. One account suggests that Jews arrived in the Yemen during the reign of Belkis, the Queen of Sheba/Yemen, and the reign of King Solomon of the Kingdom of Israel (965-925 BC) (Abu Jabal 1999: 16). Sources mention that Solomon sent a letter to the queen of Yemen asking her to come to Jerusalem. After their meeting, the Queen of Yemen embraced Judaism. This is mentioned in Quran too when the Queen enters Solomon palace, she said "My Lord, indeed I have wronged myself, and I submit with Solomon to Allah, Lord of the worlds" (Quran 27/44). Tudor Parfitt assumes that when the Queen of Sheba left Jerusalem to return home, she was accompanied by a number of Jews who, since their arrival, settled in the area (Parfitt 1996: 3). ${ }^{3}$ Another tradition assumes that the Jewish community in Yemen was founded by a group of Jews who rose against Moses during the Exodus and made their way to Yemen (Parfitt 1996: 3). It is also believed that Jews might have left to the Himyar in $70 \mathrm{AD}$ following the destruction of Jerusalem by Titus (Parfitt 1996: 7). Another account suggests that King Solomon sent his men to Yemen to bring gold and silver to adorn his Temple in Jerusalem and some of them never returned (Blady 2000: 7). Another myth assumes that in $586 \mathrm{BC}$, after the prophecy of Jeremiah, a group of seventy five thousand Jews fled southward into the desert until they reached Yemen (Parfitt 1996: 3, Tobi 1999: 3). ${ }^{4}$ Another legend maintains that the father founders of the Jewish community arrived in the Yemen through a cave whose one opening was in Eretz Yisael and the second one on the slopes of Mount Nukum ${ }^{5}$ (Parfitt 1996: 3-4). ${ }^{6}$ Still another account suggests that the Jews first reached Yemen just before the destruction of the first temple by the Babylonians (Tobi 1999: 3).

The Himyarite Kingdom or Himyar (2nd century BC - 6th century AD) was one of the most powerful, prosperous and wealthy kingdoms of Yemen and was the last one before the advent of Islam (Tobi 1999: 3). The Himyarites were greatly influenced by Judaism and during the reign of King Tubba Abu Karib As'ad (385420 AD) Himyar converted to Judaism. ${ }^{7}$ It is believed that by the 4th century Himyar was almost a Jewish territory (Parfitt 1996: 8). ${ }^{8}$ However, the subsequent centuries

3 See also Al-Hasan 2014: 76. (Arabic)

4 This took place forty-two years before Jerusalem was destroyed by Nebuchadnezzar and after the prophecy of Jeremiah - "He who remains in the city (Jerusalem) shall die by the sword, by famine and by pestilence: but he who goes forth to the Chaldean shall live."

5 Mount Nukum is a mountain in the eastern part of Sana'a, at an elevation of more than 7,200 feet $(2,200 \mathrm{~m})$ above sea level.

6 Those who believe in this myth say that today the entrance to the cave is lost but it will reopen only with the coming of the Messiah. On that day, the scattered Jews will triumphantly return to their home (Parfitt 1996: 3-4).

7 Other historians argue that the conversion took place during the reign of Yusuf Dhu Nawas (517 - 25$27 \mathrm{AD})$, the last king of Himyar.

8 Bodies of some Himyarite Jews were discovered in tombs in Beit Shearim in the Lower Galilee. These bodies, it is believed, were sent from the kingdom of Himyar to Eretz Yisrael for burial (Tobi 1999: 3, Parfitt 1996: 13). 
were fatal for Jews and Judaism in South Arabia. In the fourth century Christianity arrived in Yemen (McCord 2018: 866). ${ }^{9}$ Since then a bitter conflict between Judaism and Christianity started which culminated in the massacre of the Christians of Zafar, Mocha and particularly Najran (Parfitt 1996: 8). Eventually, in 525 Dhu Nuwas ${ }^{10}$ was defeated and Yemen, now almost a Jewish state, was ruled by Christians.

In $629 \mathrm{AD}$ the Muslim era in Yemen started. ${ }^{11}$ In the early years of Islam, the Jews were offered two choices: embracing Islam or paying Jizya (poll Tax). ${ }^{12}$ They chose the latter. However, things changed during the reign of caliphate Omar ibn Abd alAziz (717-20), who issued what is known as Pact of Omar which was a decree of protection extended by the Muslim collectivity to the protected people (Parfitt 1996: 15). ${ }^{13}$ Since then, "the status of the Jews declined as they were no longer ordinary citizens but dhimmis - protected people" (Tobi 1999: 4). However, the state granted them full freedom of religion and protection of the self and property (Klorman 2014: $6)$.

In 897, the Zaydi dynasty was founded in Yemen by Yahya ibn al-Husain bin alQasim Ar-Rassi. ${ }^{14}$ Born in Medina in 859, he chose Yemen to establish his kingdom due to its political instability and loose rule. In 901, he conquered Sana'a and was crowned the first Imam in Yemen. ${ }^{15}$ Hayyim Hibshush presents the Zaydi king "as a persecutor of all who were not Muslims in Yemen" (Tobi 1999: 12). ${ }^{16}$ In 1162, Abdal-Nabi ibn Mahdi became the ruler of Yemen. He offered the Jews two choices only: conversion to Islam or death. This led to mass conversion. However, many chose martyrdom (Maimonides 1993: 91). In 1173 Ibn Mahdi was defeated by the brother of Saladin and the persecution ended. Jews were allowed to return to their faith.

The Rasulids ruled from 1229 to 1454 . During this period the country enjoyed prosperity and stability. The Jews, too, enjoyed social and economic prosperity. ${ }^{17}$

9 It is said that the new religion was brought to the Yemen by St. Thomas (Parfitt 1996: 7).

${ }^{10}$ Dhu Nuwas was a Judaic king of Himyar (517 and 525-27 CE). He became renowned on account of his military exploits against Christians.

${ }^{11}$ Some sources say that Yemen submitted to Islam in 630 (Klorman 2014: 5). For more details on the arrival of Islam in Yemen, see Al Shuga'a (2013: 37-72; Arabic).

${ }^{12}$ The poll tax required from the Jews was generally lighter than (Zakat) which was collected from the Muslims.

${ }^{13}$ The Arabic term used to refer to Jews and Christians living in the Islamic state is Ahl al-dhimma or dhimmis - protected people - who are obliged to pay Jizya (a poll tax).

${ }^{14}$ He claimed to be a descendant of Ali ibn Abi Talib, the chief of the Shi'a and the blood cousin and son-in-law of Prophet Muhammad.

${ }^{15}$ Thus 901 is considered the year of the establishment of the Zaydi kingdom in Yemen.

${ }^{16}$ Hayyim Hibshish writes that the king Al-Hadi Yahya decided to clean Yemen of other faiths: "Only in the cities of these peoples not a soul shall live because you shall surely banish them - the Jew and the Christian, the Ethiopian and the Persian, the Indian and the Egyptian. For the said king wished to cleanse the land of Yemen of all (alternatively: of the defilement of all) members of another faith, and their forefather Ali, the commander of the faithful, bequeathed the land of Yemen to them... and therefore he commanded to destroy and kill and wipeout all who were not his ally if they did not accept his creed" (As cited in Tobi 1999: 9).

${ }^{17}$ According to Yosef Tobi, the era is marked by the absence of persecutions against Jews. Furthermore, "the Rasuli era in Jewish Yemenite history is marked by its significant spiritual and literary output, which is the greatest in its history" (Tobi 1999: 5). 
However, this changed with the rise of the Tahiri dynasty (1454-1517). During the Tahiri reign the social and economic situation of Jews deteriorated because the Tahirids introduced new discriminatory acts. The Tahirids" "attitude to the Jews was rigid. They ousted almost all the Jews from the areas they inhabited, on the pretext that they were sacred and non-Muslims may not live there" (Tobi 1999: 6). In 1499/1500, during the reign of the last king of the Tahirids, Amir ibn Abd alWahhab, the Jewish Messiah was active in Yemen. And this angered the king, whose "response was a collective punishment" (Tobi 2013: 249). ${ }^{18}$

The first rule of the Ottomans began in 1546 and ended in 1630. The Ottoman rule "improved the legal status of the Jews" (Tobi 2013: 250). This "change was part of the general policy toward the minorities in the Ottoman Empire" (Tobi 2013: 250). ${ }^{19}$ The Zaydis were able to expel the Turks from Yemen in 1635 and Yemen once again came under a Zaydi regime. The new Zaydis were "religious fanatics and far stricter than the Sunni Ottomans ... in their treatment of Jews" (Tobi 1999: 50). According to some sources, the new "regime was the most hostile to the Jews of Yemen as local Muslims took revenge for the relatively comfortable attitude of the Turks to the Jews and because of the aforementioned alleged argument that the Jews sided with the Turks" (Tobi 2013: 251) ${ }^{20}$ It was during this period that the Zaydis did "fully apply the discriminatory laws against Jews" (Tobi 2013: 251) ${ }^{21}$ and therefore, the Jews" "lot deteriorated under the Zaydi yoke" (Tobi 1999: 50).

In 1667, during the reign of Imam al-Mutawakkil Ismail (1644-1676), a great event happened that changed the life of Jews in Yemen forever. They heard that the promised Messiah and Redeemer had arisen. Sabbatai Zevi was the long-awaited messiah. ${ }^{22}$ Thus, the Jews of Yemen, especially in Sana'a, went to the streets to express their messianic aspirations. The Imam "decided to strip them of all their rights as a protected religious minority" (Tobi 1999: 6). The Imam, as a sign of humiliation to the Jews, imposed many new discriminatory laws such as prohibition to wear headgear (Klorman 2014: 37, Tobi 2013: 252). ${ }^{23}$ The leaders were arrested and tortured, and the sentence of death hovered over them. Further, in 1679, the Jews were expelled to Mawza, a place near Mocha, the Red Sea port in west Yemen.

${ }^{18}$ This led to the extinction of entire Jewish communities in some parts of Yemen. Yosef Tobi writes that since "the end of the fifteenth century ... there were no Jewish communities in Hadramawt, save along the western periphery" (Tobi 2013: 249).

19 The Ottoman rule allowed the Jews of Yemen a chance to contact other Jewish communities and Jews started their contact with the Kabbalists in Safed, and with other Jewish communities throughout the Ottoman Empire. This is because the Ottomans implemented the principles of the Hanafi school of Islam which was much more tolerant to non-Muslim minorities throughout the empire.

${ }^{20}$ The Jews were accused of siding with Turks and acting against the interests of Yemen (Tobi 2013: 251). And therefore, the "Zaydis treated the Jews more severely, not only in comparison to the Turks but also in comparison with the ancient Zaydi policy" (Tobi 2013: 251).

${ }^{21}$ See Tobi 2013: 251-252.

${ }^{22}$ The messianic movement in Yemen grew precisely out of information arriving from Erez Israel and Egypt through letters and messengers that the King Messiah of Israel had arisen for the Jews.

${ }^{23}$ According to Yosef Tobi (2013), the headgear (Amaim) was "a respected status symbol" and the Jews "were forced to walk bareheaded, the most despicable thing in Yemeni society in those days" (252). 
This disastrous event is known in the history of Yemenite Jews as The Expulsion of Mawza. ${ }^{24}$

The Turks reconquered Yemen in 1872. In fact the Jews, due to the political, social and economic circumstances, have been waiting for any foreign power to intervene or even control the affairs of Yemen (Tobi 1999: 86). When the Turks conquered Yemen, the Jews even helped the Turks by weaving plots and providing them with intelligence (Tobi 1999: 86). The status of Jews improved drastically between 1872 and $1918 .{ }^{25}$ However, their status deteriorated after the Ottomans left the country in 1918. During the rule of Imam Yahya (1904-1948), all traditional laws concerning Jews, including Orphan's Decree and the poll tax, were revived. ${ }^{26}$ The Jews again became protected people. He even destroyed the new synagogues that were built during the Ottoman rule in Sana'a. ${ }^{27}$

The Jews' history in the Yemen is "an unending chain of persecution and humiliation" (Parfitt 1996: 6). That is why "[D]uring the long centuries of exile, the Jews had prayed for an abrupt and dramatic end to their existence in Yemen, a time when their triumphant remnant would return to the Holy Land on the wings of eagles, as foretold by the prophets" (Tawil 1998: 14). So, the life of Jews in Yemen has witnessed many ups and downs. It was stable and prosperous at times and faced declination and oppression at other times. And due to the difficulties that the Jews faced in Yemen, they were among the early immigrants to leave for Israel. ${ }^{28}$

${ }^{24}$ On the messianic activity in 1666-1667 and its consequences, the decree against headgear and the Expulsion of Mawza see Tobi 2013: 252-255. This episode of the history of Yemeni Jews will be discussed in detail while discussing the novel.

${ }^{25}$ The Jews are no longer protected people as Ottoman government had abolished the jizyah. This was part of a general plan throughout the Ottoman Empire which granted equal status to minorities, including Jews. Further, the Turks announced their intention of abolishing the humiliating discriminatory laws that had been enacted against the Jews (Tobi 1999: 87, Klorman 2014: 13). However, most of these intentions never came to fruition for they aroused the rage of the native people. So, many discriminatory acts were still valid (Tobi 1999: 89-90).

${ }^{26}$ For more details on these discriminatory acts and laws see Ken Blady 2000: 10-11; Tobi 1999: 89; Parfitt 1996: 15-6.

${ }^{27}$ During the reign of Imam Yahya, "Jews were not allowed to leave the country, their economic system was severely injured by government policy, and worst of all the Zaydi orphans' edict was reinforced" (Tobi, 1999:. 7)

${ }^{28}$ Ari Ariel (2014) writes that Jewish immigration to Israel has three periods: period I: 1881-1910, period II: 1911 to World War II and period III: World War II to 1950. In the first period, "migration was organized by small groups of Yemeni Jews and provoked primarily by push factors in Yemen, particularly political and economic instability. That is, the movement began as an organic response to local conditions and was not connected to the Zionist movement or Zionist ideology" (9). The second period "witnessed the entrance of the Zionist movement into the Yemeni arena ... From these moments on, the Zionist movement would be a primary force directing Yemeni Jewish movement" (9). During the third period, the number of immigrants increased dramatically due to many reasons such as the conflict with the British in Aden and the airlift known as Operation on Eagles Wings.

Ariel also discusses the different factors that provoked the Jewish immigration. In addition to the push factors which force people of certain communities to immigrate, there were the economic factor, the ideological factor, the religious factor and the political factor. All these combined are behind the immigration of Jews. Though the effect of these factors differs from period to period. 


\section{The Handsome Jew}

In its general drift, The Handsome Jew is a love story. Fatima, a young Muslim woman, falls in love with Salem, a young Jewish boy. The relations between the two lovers are marked by inequality: both are ethically, religiously and racially different. Fatima belongs to a rich family; she is the daughter of Mufti (a jurist who interprets Muslim religious law), the highest position in the Muslim religious ladder. Salem is the son of a poor, simple Jewish craftsman. He gathers wood for the Mufti. He does not sell the wood for price but gets things such as corn, bread and sweets in return (Al-Muqri 2011: 7). Fatima used to receive him, take the wood from him and sometimes give him food or tea. She falls in love with him though he is younger than her and her family does not recognize the love affair that is growing between the two because in their opinion Salem is still young and belongs to another religion and community. Fatima confesses her love to Salem, and both live for years in love. After seven years of surreptitious love - knowing very well that their families will never accept their marriage - Fatima and Salem decide to elope and leave Raydah ${ }^{29}$ to Sana'a where they can marry and freely lead their own life. However, their happiness does not last. Fatima, after only one year, dies in childbirth. Since their first meeting, Fatima calls Salem 'my handsome Jew,' hence the title of the novel.

Fatima stands out as a symbol of tolerance, coexistence, open-mindedness and love. She sees all human beings as the creation of God regardless of their religion. Speaking to Salem's father, she says:

What I taught him was Arabic language and grammar so that he can read and write. I know he is a Jew. To you be your religion and to us be our religion. There is no problem. We are descendants of Adam and Adam is from the earth ... Let me tell you, I swear, there are many books on the shelves at our home which, if the Muslims read them, would make them love the Jews, and if the Jews read them, would make them love the Muslims (Al-Muqri 2011: 15-16).

Her decision to marry Salem, the other, is born out of her conviction that all people are equal. Further, Fatima breaks the familiar Muslim rules and visits a Jewish home ${ }^{30}$, and learns Hebrew and Jewish law. Moreover, Fatima's tolerance and her respect of others' opinion is seen when she follows a fatwa by Abu Hanifa, the founder of the Hanafi school of Sunni jurisprudence, to marry Salem. Her father the Mufti follows the Zaydi-Shiite doctrine. It follows that Fatima should follow the same doctrine. But she does not hesitate to follow another religious doctrine. That is, she obtains a fatwa from a scholar in a doctrine other than her own.

Fatima's coexistence, tolerance and love for the other is juxtaposed with the larger community's religious and racial intolerance and hatred. The Zaydi community is portrayed as violent, hateful, and simple-minded enough to be incited by its leaders. Its religious and racial ideology is the fundamental source of the motivations that

\footnotetext{
${ }^{29}$ Raydah or Raida is where the novel takes place. It is a market town located 49 kilometers north of Sana'a. It once had one of the largest Jewish communities in Yemen.

${ }^{30}$ It is a big shame for a Muslim woman to visit a Jewish home but not vice versa.
} 
led to the victimization of Jews. The Zaydis actually claim they descend from Prophet Muhammad and have a divine right to rule. Descent from Muhammad means descent from Al-Hasan and Al-Husain, the offspring of Fatima (Prophet Muhammad's daughter) and Ali ibn Abi Talib (Prophet Muhammad's cousin and the last of the Righteous Caliphs). They call themselves Hashmites (descendants of Hashim, the grandfather of Prophet Muhammad) and Ahl Al-Bait (means belonging to the Family of Prophet Muhammad). They have enjoyed a high status and respect due to their alleged ancestry. However, they have oppressed all other Yemenites whose religious beliefs are different: no difference between Sunni Muslims or Jews. ${ }^{31}$ They see themselves as God's representative on earth and that Imamate/leadership is their heavenly right. ${ }^{32}$ They were created to rule. Hence the Muslim community is duty bound to align itself at the side of, and to obey, any descendant of Muhammad who nominates himself to the position of leadership, provided that an individual fulfills a list of requirements. They have committed horrible crimes and massacres in the name of God. The last war in Yemen between Houthis and the Yemeni legitimate regime that started in 2014 and is still running until today is just an example.

As a historical novel, The Handsome Jew recounts briefly the history of Yemenite Jews focusing mainly on the seventeenth century. The novel is an attempt to revive lost history, memory and identity. In other words, the novel is a revisit to a forgotten period of Jewish history in Yemen. It is a daring novel because it discusses a topic which has never been discussed before - the marginalization and persecution of Jews in Yemen. The time setting of the novel is highly significant as the seventeenth century witnessed devastating and terrifying events, which had no precedence in the annals of the Jewish history and that changed the life of Yemenite Jews forever. It was during the seventeenth century that the news that the long-waited-for Jewish messiah had emerged. The consequences of this movement had a tremendous effect on the life of Yemenite Jews. Many of the discriminatory laws were issued during this century. Their expulsion to Mawza, the confiscation of their property, the looting of their possessions all took place during this century. The reader comes to know the condition of the Jews at the time, their struggle to follow their religion and preserve their Jewish culture and heritage in the face of a Zaydi regime and community that persecuted them by words and deeds. The novel's further merit is that it raises questions in the reader. After reading the novel the reader faces a new challenge - to read about the Yemenite Jews in the books of history to answer the many questions raised by the novel.

The Handsome Jew demonstrates how the Yemenite Jews are always reminded of their otherness and unbelonging. They are always told that they are unwanted and have to find another place for living as they do not belong to this soil. The Zaydis consider the Jews as outsiders and not Yemenites and, therefore, they must leave the country. Sheikh Saleh, the Muezzin, is a Muslim fanatic who cannot bear the sight of Jews. Though he is the one who calls for prayer and represents Islam, he is full of hatred and animosity. Whenever he meets a Jew, he yelps "when are you going home?" The first words Salem hears from the Muezzin are "When are you

${ }^{31}$ See Al-Muqri 2011: 126.

${ }^{32}$ See Hadi Mohammed Saleh 2016: 23. 
going to leave the land of Arabs?" (Al-Muqri 2011: 35). Next time he speaks the words but in a different way "when are you leaving to your home?" Salem's father painfully replies "Where shall we go? Where is our home?" and the Muezzin replies, "You say that Jerusalem is your home! Go there ... or go to hell" (Al-Muqri 2011: 35). Saleh's words are always a source of tension, irritation and stress particularly to Salem's father and As'ad, a Jewish cobbler. Whenever their day is poisoned by Saleh's words, they spend the rest of the day discussing the possibilities of leaving for Jerusalem or living here in Raydah (Al-Muqri 2011: 35). Saleh's behavior presents a negative image of Islam to non-Muslims particularly the dhimmis who live under the protection of the Muslim state. That is why Muslims get a negative response from the Jews. For example, As'ad is a not fanatic Jew but he does not like Muslims and always has verbal clashes with Saleh. He calls Muslims "cursed infidels (Kafirs)?" (Al-Muqri 2011: 17). However, his argument with the Muezzin shows his deep knowledge of Islam. This is a sign of his open-mindedness and readiness to learn about the other. Unlike Muslim scholars who are much less open to learn about the Jewish religion and traditions. Maybe because "there was nothing to be expected of the religion of a despised and weak nation" (Tobi 1999: 157). Another situation which shows the otherness of the Jews takes place when Hussein, the son of their neighbor in the market, asks "Where are you from?" and Salem replies "From Rayda. From this land" (Al-Muqri 2011: 22). Hussein shouts, "It is not your father's country. This is our country. You are an infidel Jew" (Al-Muqri 2011: 22). So, when a Zaydi child insults him with 'infidel' and tells him he is not here at home, or when Saleh the muezzin every day asks them to leave "the land of the Arabs,' Salem wonders, "Who are we?" (Al-Muqri 2011: 22). This shows the close connection between home and identity.

Salem and other Jews are always considered as inferior. The Zaydi leaders have inculcated the feeling of superiority in the hearts of the Zaydi community. When Salem goes to the Imam to declare his Islam so that he and his son can survive, Ali introduces him to Imam but before that he tells the imam 'Azakum Allah.' This phrase is said before uttering a Jewish name showing that the speaker is going to utter something inferior or despised (Al-Muqri 2011: 105). This phrase shows the humbleness, lowliness and inferiority of the Jews' status in the Yemenite society. It is a sign of degradation, disgrace, humiliation and ignominy. Further, throughout the novel when the word 'Jew' is uttered it is followed ${ }^{33}$ by the word 'cursed' which is a big insult in the Yemenite traditions.

Al-Muqri attempts to underline the victimization of the Jews by highlighting the atrocious cruelty and mad violence of the Zaydis who never hesitate to physically attack the Jews whenever they have a chance. The wine attack is just an example. One day some Zaydis attack a Jewish neighborhood and smash containers of wine. They claim that the Jews spoil the young Muslims by selling wine to them. The problem is that if they sell wine to Muslims, they are attacked by religious fanatics and if they do not sell, they are also attacked by Muslim addicts. And when they go to complain to the government they are not believed, and their witness is not accepted by the Zaydi jury.

${ }^{33}$ In Arabic, unlike English, the adjective follows the noun. 
The Handsome Jew revisits one of the watersheds in the history of Yemenite Jews, the messianic movement. The novel shows how such a messianic activity is given a political dimension by the Zaydi rulers so that as to vindicate their oppression of the Jews. In 1666 the Jews of Yemen were informed that the long-awaited King-Messiah had arisen, and his name was Sabbatai Zevi. Born in 1626 in Smyrna, and died in 1676, Sabbatai Zevi ${ }^{34}$ proclaimed himself Messiah, raising the hope of liberation of the Jews in many countries. Like other Jews all over the world, when the Yemenite Jews heard the news, "they were very happy and excited as if they had no other dream but to wait for him" (Al-Muqri 2011: 117). The messianic activity has been nurtured among the Jews "by the expectation of redemption by one of the progeny of the House of David, who would restore the exiles to the land of Israel and there renew the Jewish kingdom" (Tobi 1999: 48). First the kingship of the world will go for them; second, they will return to their promised land. The novel details this event in Yemen to show the Jewish joy for returning home and ruling the world. The moment the news of the new messiah arrives in Yemen, the Yemenite Jews begin to show signs of joy and delight. They "started in the first week of Shaban ${ }^{35}$ to sell their homes, possessions and property very cheaply" (Al-Muqri 2011: 119) and made preparations for their ascent to the Land of Israel. The sale of their belongings was accelerated and "many of them stopped working and gave their money away as donations and loans" (Klorman 1993: 33). The messiah represents freedom, salvation and redemption for the Jews. Their dream of freedom and returning home is connected with his arrival. The Jews' self-respect and dignity will be restored after centuries of suffering, powerlessness and humiliation.

The central figure of the 1667 messianic movement in Yemen is Sulayman Jamal Al-Aqta, one of Yemenite rabbis. He is a Jewish nagid (leader) who is also in charge of collecting Jizya from the Jews. He leads a group of Jews in Sana'a to express their messianic aspirations in connection with the larger Sabbatean movement all over the world. Hamami, who lived and witnessed these events, describes him as "great and versed in torah and in the Bible and in the halakhot and the aggadah and the qabbalah, but mostly in the qabbalah, and a great thing happened to him" (as cited in Tobi 1999: 70). According to Tobi, the 'great thing' refers to "some revelation or divine illumination that aroused within him the feeling that he himself was the Messiah or at least that he was to play a central part in the course of the redemption" (Tobi 1999: 70). Sulayman al-Aqta, as Klorman (1993) says, "underwent some sort of inspiring vision ... After his vision, which probably instructed him as to what should be done, Sulayman al-Aqta initiated a bold action to remove what seemed to be the final obstacle to the messianic appearance - the Zaydi government" (41). According to A-Muqri, Sulayman al-Aqta is a rabbi and the Jews do not see anyone better than him to rule Sana'a. They give him expensive attire which resembles the attire of kings, perfume him and adorn him with jewels (Al- Muqri 2011: 122). The event has been described by historians such as Klorman, who writes: Sulayman

${ }^{34}$ Eventually, Sabbatai Zevi was imprisoned by the Ottoman Sultan who offered him the choice between death and conversion to Islam and he preferred the latter, leaving everyone who had followed him in dismay.

${ }^{35}$ Shaban is the eighth month in Islamic calendar. It comes before Ramadan. 
mounted the palace in the fortress of Sana'a ... to challenge the authority of Sayyid Jamal al-Islam Ali, the governor of the town ... [he] prepared for his mission in a festive manner appropriate to a happy bridegroom on the eve of his wedding day. Like a bridegroom, his hair was shaved and perfumed with expensive perfume, and he was dressed in a beautiful white silk robe" (Klorman 1993: 41-42).

When he arrives at the palace, all alone, he steps forward carelessly, without fear. He speaks to the prince in Hebrew, with words that nobody understands. They bring a translator. The interpreter does not believe his ears and does not dare to reveal what he has heard; however, he translates: "He tells you: Get up and leave your throne. Your kingship is over. Your days have gone. Kingship is for us now" (Al-Muqri 2011: 123).

But instead of getting the throne, Sulayman is arrested by Jamal al-Islam Ali, the governor of Sana'a and thrown into the Bustan prison in Sana'a where he was "locked ... in a place of snakes and scorpions" (Tobi 1999: 73). Then the Imam orders "that he be executed as a rebel against the kingdom who had grievously violated the protection agreement between the Zaydi state and the Jews" (Tobi 1999: 73). However, before the beheading, Jamal is offered to convert to Islam in order to save his life, but he contemptuously rejects this offer. As if death is not enough, the Zaydis then drag his naked corpse and hang it on Bab Shu'ob ${ }^{36}$ for three days. He remains there for several days, until his fat (he was obese and paunchy) runs on the walls; and when the corpse starts to rot and people are disgusted by the smell, the Jews are ordered to pull him down.

However, the death of Jamal does not mean the end of the suffering of the Yemenite Jews. They are imprisoned collectively, extra taxation is imposed, fines are levied, and many more discriminatory laws are issued including the Decree of the Turban, with which they are forbidden to wear turbans or headdresses. The state confiscates all their property (both movable and immovable). They are stripped from the right to own or possess lands. Their houses have to be lower than those of the Muslims. The construction of synagogues is no longer allowed, and the cult is conducted in private houses, transformed into prayer rooms. They are prohibited from riding camels and horses (they could ride only donkeys, and only with both legs on one side, like women). They cannot possess or carry arms (in Yemeni society the right to bear arms distinguishes the freemen). "After the killing of Sulayman al-Aqta," Al-Muqri writes, "the Jews were much more humiliated and degraded ... A chain of punishments were issued against them. Their money and unsold land was confiscated. He even sent his soldiers to register the names of the Jews all over the kingdom. Then he decided to raise the jizya 20 times extra" (Al-Muqri 2011: 125). After nearly three years and due to the new decrees, "some Jews died of hunger and some who survived converted to Islam" (Al-Muqri 2011: 125).

Undoubtedly, the response of the Imam Isma'il is very harsh as he perceives this as an actual insurrection. According to Tobi, Isma'il

${ }^{36}$ Meaning gate of Shu'ob. One of Sana'a's main gates. 
decided to take drastic action against the Jewish communities, no doubt on the assumption that the Jews had violated the conditions of the protection agreement between the Islamic government and themselves by rebelling against the former. Instructions went out from Sudah to all the cities of Yemen and its provinces to strike at the Jews. And sure enough, the orders were fulfilled by the Imam's own troops dispatched from Sudah and presumably by local populations everywhere (Tobi 1999: 71).

To fully impose his control on the Jews, a political dimension is added to the messianic movement which "was perceived by the rulers as a revolt ... This was because the nature of a messianic movement was to alter the order of government" (Tobi 1999: 68). It is seen as "a violation of the laws of protection granted them by the Islamic State, an act that released the state from maintaining the protection. The significance of this ruling was that Jewish blood and property were now free for all because the state was not obliged to protect them" (Tobi 1999: 68). ${ }^{37}$ As soon as the protection is no longer valid, the Zaydis of Kawkaban and Shibam attack the Jewish families and loot their furniture, jewels and money (Al-Muqri 2011: 119). It does not take long for the news to reach Hamdan, Al-Aroos, Hodoor and bilad al-Bustan who seize the opportunity and ransack the property of all the Jews in the area (Al-Muqri 2011: 120). Furthermore, the Imam enforces the laws of discrimination against the Jews that were practiced in other Islamic states in addition to the local ones. Further, Jewish leaders "were arrested and tortured in several prisons, and the sentence of death hovered over them" and to save their lives the Jews sentenced "were offered their lives in return for conversion to Islam" (Tobi 1999: 72).

One of the darkest moments in the history of Yemenite Jews is their exodus to Mawza. ${ }^{38}$ Al-Muqri masterfully details how the Jews are treated as non-humans, objects that could be easily disposed of, or willingly erased. The Jews are no longer the masters of their lives which are now totally controlled by the Zaydis. The Imam Isma'il resolves to expel the Jews from Yemen. But due to his death, the act of expulsion was carried out by his successor Imam Ahmad. The Imam Ahmed adds a religious dimension, in addition to the political one, to his decision and justifies his action by quoting a Hadith by prophet Muhammad: "Drive out the Jews from Hijaz"; in another version: "Drive out the infidels from the Arabian Peninsula" (AlMuqri 2011: 129). The Jews are expelled from all Yemen and sent to Mawza, a torrid and scorching area on the shores of the Red Sea. There, about half of them died of hunger, disease and hardship. Describing the condition of the Jews during and after their exile in Mawza, Yosef Tobi writes:

This event was disastrous for Yemenite Jewry owing to its serious economic, political and demographic outcome (more than half of the Jews disappeared during this exile) as well as its spiritual consequences. Uprooted from their ancient dwelling places they were cut off from their traditions ... From then on they were treated as unclean persons, forbidden direct contact with Muslims. Moreover, they suffered a profound social

\footnotetext{
${ }^{37}$ See Al-Muqri 2011: 119.

${ }^{38}$ Mawza is a district of Taiz Governorate, Yemen. It is located on the Red Sea shore.
} 
and moral crisis in consequence of the exile, as the temporal and spiritual leadership was insufficiently respected by the members of the community. There is even some evidence of prostitution in the Jewish community, unimaginable under other circumstances (Tobi 1999: 6-7).

The Jews are panic-stricken as the future becomes darker and bleaker. They have suffered too much and hoped too much. Now they are exasperated beyond endurance by the hostile and aggressive attitude of the Zaydis. They are highly disappointed, and their hopes are thoroughly lost.

Al-Muqri presents a touching and heartbreaking portrait of Jewish exodus. He writes: "Of course, they did not weep. Expulsion decree gave them no time to do so. It appeared that their destination will be opposite to their dreams. To there. To the unknown" (Al-Muqri 2011: 131). It is a journey to the unknown. They have left their belongings, their dreams, their hopes, and their future. They do not know where to go. When Salem sees the Jews gathering at the outskirt of Sana'a ready to leave, he says: "I was hit by the sight of the Jews gathered to leave Sana'a with a heartache that has not yet been recovered until now. Those who still have some possessions sold them cheaply" (Al-Muqri 2011: 133). Seeing their horrible condition, Salem decides to accompany them in an honor for Fatima. He buys a donkey and rents another to help the poor ones carry their belongings and to ride one if he gets tired. But that does not happen. There were many "old women being carried on backs, and old men creeping like infants; they cannot stand or walk even a single pace. Pregnant women with infants, uncountable sick persons. What can two donkeys do for them" (Al-Muqri 2011: 134). Salem gives the first donkey to an old man and the second to a young woman who had an abortion. She says that the abortion happened because she spent the night without cover. Later he discovers that the young woman is his daughter-in-law, Said's wife (Al-Muqri 2011: 134). Thousands of children, women, and old men are struggling under the heavy weight of bundles making their way painfully down to the scorching shores of the Red Sea in a sinister tumult. Some faint and are trampled by the surging crowds. Moaning and sobs are mingled with cries. Women carrying babies are wailing and weeping. Some people fall by the wayside, and some do not rise again. "Many people," writes Al-Muqri (2011), "were reluctant to walk with the surging crowds, they were incapable of any movement. They chose the simple and easy path; they refused any help and surrendered to the coma of eternal death. We can do nothing for them except burying them as much as we can" (136). However, "it makes no difference whether we bury them or leave them without burying for the wind and crows. The whole earth has become a cemetery" (Al-Muqri 2011: 136). After three days they arrive at Mawza. ${ }^{39}$ Salem

${ }^{39}$ The region of Mawza was inhospitable, unhealthy and very hot, and it is estimated that about one third of the Yemenite Jews died of hunger, thirst and disease during the march to reach it. But after a short time in exile, considering the need that the economy of the country had for Jews as artisans and small traders, they were allowed to return. However, the Jewish presence was afterwards considered to be unclean and contaminating for Muslims, so it was forbidden for Jews to return to their ancient dwellings, and they were forced to build separate neighborhoods, generally outside the walls of the town. 
wonders, "Is it the order of Imam to leave us here or the whim of a soldier got tired of the creeping of the sick, the hungry and semi-dead bodies?" (Al-Muqri 2011: 137). Describing the new place, Salem says: "Our stay in this hot place is like our traveling to here: Hunger and fever accompanied all of us. Nothing can stop the mosquitoes from sucking the blood of the arrivals. Death is a final rescuing dose as an expected healer" (Al-Muqri 2011: 137). It is the catastrophe of the Yemenite Jews. It is this catastrophe and its pain and suffering that Al-Muqri brings to life in this novel.

The intensity of persecution and humiliation is clearly seen in the Jews' willingness to take revenge. The ill-treatment that the Jews receive at the hands of the Zaydis makes them think of revenge. When the news of the new messiah arrives in Yemen, the Jews start to threaten the Zaydi Muslims. They will avenge the wrong things done to them. Here we can affirm that the Jews' intention to persecute the Muslims when their kingship comes is reactive and not proactive. It is a reaction to the persecution they experienced at the hands of Zaydis. It does not spring from an evil spirit but rather a reflection of past oppression and persecution. It is a reaction to the debasement of status facing them every day. In other words, with the arrival of the news of the newcomer, the life of Jews is entirely altered. Some of them cannot hide their joy and start to express such joy in a way unfamiliar to the Zaydis. Salem's brother Haza' a dies because of fever. He was 23 years old. He is a fanatic. He assures his brother of the coming of the liberator and future redeemer of the Jewish people. Then he will take revenge and fight all Muslims. Angrily, he says: "on that day, I will avenge myself on all Muslims, even those who have done nothing to me. It is enough that they were silent. I will cause abortion of the fetuses before they are born, and if they are born I will never let them grow to become strong enemies. They are enemies before they are born, even before they are created" (Al-Muqri 2011: 32). A Jewish cobbler says to a Zaydi Muslim while stitching his shoes: "You will see, we will make you kneel before us; we will take revenge; we will make you walk barefooted. Jews alone will wear shoes. And as for you, you have to manufacture their shoes and repair them" (Al-Muqri 2011: 118). Some others intend to impose jizya on Muslims and it will be doubled. Another Jew while selling an axe for a Muslim and while bargaining, he says: "Give me whatever you like. Today it is for you and tomorrow for me, with which I will hit your head" (Al-Muqri 2011: 118). Some other Jews threaten the Muslims that they will destroy everything Muslims have built in Jerusalem and build synagogues in the place of mosques (Al-Muqri 2011: 118). The dream to rule the whole world, is expressed by As'ad when he says: "The Jews will not live in Jerusalem only, but they will rule the whole world. When the messiah arises we will rule from Jerusalem, ah ... ah ... the authentic Jew, the Jew and the son of the Jew, and no one else, will sit on the throne in Jerusalem and will give his orders to eliminate all the enemies. This is the will of the lord" (Al-Muqri 2011: 52). This reaction of the Jews can be understood if we follow their history in Yemen. They have been suffering for more than two millenniums at the hands of local people. In her discussion of the human response to perceived injustices, Hannah Arendt (1970), argues that human beings react with rage and resort to violence: "Rage is by no means an automatic reaction to misery as such ... Only 
when our sense of justice is offended do we react with rage, and this reaction by no means necessarily reflects personal injury" 63). Talking about the violence that rises between the colonizers and the colonized, Jean-Paul Sartre (1963) writes: "for at first it is not their violence, it is ours, which turns back on itself and rends them; and the first action of these oppressed creatures is to bury deep down that hidden anger which their and our moralities condemn and which is however only the last refuge of their humanity" (18). Like the colonized, As'ad's comments are reactive and never proactive. He has been subject to injustice for years and his anger as stated by Ardent and Sartre is vindicated.

The Yemenite Jews are not given the chance to settle down or to feel that they are Yemenites living in their land. They are not accepted and always reminded of their otherness. They are insulted, cursed, discriminated against, looked down upon and despised. They are not allowed to build strong homes. They should build their home with clay and not stones. For this reason their homes are destroyed very easily by rain. One of these houses is As'ad's house. Lamenting the oppressive Zaydi laws that do not allow them to build strong houses, As'ad says:

we cannot build our houses on a strong basis because they do not permit us to build one or maximum two storeys on the condition that it does not compete with or surpass theirs. What shall we do? Our homes if not swept or uprooted by floods, they are destroyed by rain ... they are not our home to care for. They are homes for the wind. It scatters them whenever it wants to and it scatters us also (Al-Muqri 2011: 58).

It is thus natural that their allegiances and loyalties are directed to the land of Israel rather than to the surrounding society. They feel that the current place is temporary. Further, deep inside they feel that the Jews in general have no home other than the Holy Mount in Jerusalem. These misdirected loyalties are the outcome of their ill-treatment at the hands of Zaydi Muslims and non-acceptance in the Yemeni society. They have been living in this place for millenniums, however, they are seen as outsiders who should go back to their original home. Further, they have no right to own land. This is a very critical issue. Preventing someone from owning land will always remind him that he does not belong here. There are also those publicly humiliating assignments such as latrine and toilet cleaning, carcass removal and others that make one feel inferior. They have nothing to compensate for all these except their longing and dream of return. This feeling of longing and return is what stimulated the Jewish messianic movement in Yemen among other places which has always found its expression in the chiseling of the David Star on everything they make, such as wooden doors and windows or the walls of the room. Muslims do not know the meaning of this star. They think that it is a kind of decoration (Al-Muqri 2011: 42).

The longing of the Yemenite Jews is intensified by the mean jobs assigned to them by the Zaydi regime. They are forced to clean the baths, dung and corpses from the streets. In the novel, Salem collects firewood for the Mufti. He does not sell the firewood for a price but gets things such as corn, bread and sweets in return 
(Al-Muqri 2011: 7). As'ad is a cobbler, one of the mean jobs for the Zaydis. Another unnamed character is a blacksmith. In other cultures, these may look ordinary jobs but in Yemen such jobs are done by minorities such as the Jews. It is a great shame to work in such a job. ${ }^{40}$

The longing of the Jews for Jerusalem is deepened by their isolation from the larger society. The Jews, debased and despised, and due to their inferiority, are forced to live in isolation. This is clear from the reaction of the Salem's family to Fatima's visit to their home. Salem is forbidden from going to the Muslim house to continue his learning. For this reason, Fatima comes to his home. His mother does not believe that Fatima has come to visit them. She wonders, "Is it possible? A Muslim woman at a Jewish home?!" (Al-Muqri 2011: 14). This question is crucial. Jews may go to a Muslim house but not the other way around. It is something out of nature to see a Muslim at a Jewish house. "I know," Salem's says, "that she [his mother] has met her [Fatima] many times at their home or at other Muslim homes, but what I do not know is that a Muslim female visit to the Jewish neighborhood was something unimaginable" (Al-Muqri 2011: 14). In another place in the novel, Salem says: "I do not know what the word infidel means. I only know that I am a Jew. Children who live outside our neighborhood call me a Jew. The old call our neighborhood the neighborhood of the Jews" (Al-Muqri 2011: 22-23). This shows that a warm relationship between the two communities is absent. Their relationship does not go beyond business relationships. The presence of Jews is crucial for the local economy as the Zaydis abhor almost all manual professions except agriculture. They depend on the Jews to repair the broken tools. Only the Jews could fashion jewels. Though there is a mutual trust between the two, each sect believes that the religion of the other is false.

In addition to linking persecution to politics and messianic movement, Al-Muqri also links it to religious intolerance and fanaticism. Al-Muqri opines that religious fanaticism and intolerance are behind the persecution of Yemenite Jews. As we have seen, all Zaydis justify their oppressive treatment of Jews by citing Quran or Hadiths. Yemenite Jews are the victims of misunderstood religion and bigoted fanatics such as the Muezzin and Zaydi imams who believe to represent God on earth. The novel is a call for moderate religion and tolerance. At the end of the novel, Salem summarizes those who are intolerant from both religions. These people are the poison of communal life. He comments on the death of his uncle and aunt in Mawza:

My uncle requested my forgiveness as he died on a hot summer day. But his wife did not request me. Instead she blessed me with her forgiveness on the condition that I have embraced Judaism again. But I am not sure that she has forgiven me or forgiven herself ... anyone who knows her like me knows very well that she died with all her grudge, malice and hatred. Same like my brother. And maybe like As'ad and Saleh the muezzin (Al-Muqri 2011: 137).

${ }^{40}$ The circumstances of the Yemenite Jews seem to be similar to those mentioned in Psalms 70:20: "In our exile we suffer from three calamities, the first is persecutions, wandering and slavery; the second is agony, poverty and humiliation; the third is war, abuse and famine" (136). 
To highlight his point of religious tolerance and coexistence, Al-Muqri creates Fatima, such a lovely character.

The conflict between the two communities continues even after death. Despite the hopes that the reader feels at the beginning of the novel that the intimacy between the two main characters represents and may lead to the intimacy between the two communities religiously, culturally and socially, the end is unhappy. The story, which opens with love and romance, has a tragic end. Salem, at the end of the story, decides to transport the bones (the remains) of his life partner from her isolated tomb in the Jewish cemetery to the Muslim cemetery. But what he does not expect is the attitude of her Muslim community. Four Muslim men from her family along with the grave guard come with bulldozers and exhume her body: "there is no place for this infidel except with Jews in their cemetery" (Al-Muqri 2011: 146). The bones again are buried in the Jewish cemetery. Only one day later, the Jews remove her bones and put them back in the old isolated grave. When Salem dies, he is buried in a Muslim cemetery but after just one night four men dig up the grave and take the corpse. He is exhumed also like Fatima. Though he has declared his Islam many years ago, he is not accepted. So, both Salem and Fatima are alienated in their life and in their death. They are rejected by both Muslims and Jews. Said, their only son, says: "what is this? How? The earth and the people do not accept them ... no one ... neither land nor people" (Al-Muqri 2011: 148). One day in the morning Ibrahim, Said's son, does not find his father. He is informed that some people saw him carrying a bag in his hand and went towards the east. Some say towards the west, others toward the north and still some others toward the south. Going the four directions at the same time has two interpretations: first they belong nowhere and second, they belong everywhere. The exhumation of the remains of Fatima and Salem and constant transfers of their bodies, in a kind of war between the two communities, darkens this optimistic vision of the future. Hence The Handsome Jew can be called a story of isolated graves and expelled souls.

\section{Conclusion}

Al-Muqri in this novel has given the reader a vivid picture of the suffering of the Jewish community in Yemen during the 17th century. The novel demonstrates the Zaydi persecution of Jews: discriminatory laws, high taxes, exile, and land confiscation. The Zaydis are portrayed as rabble hungry for booty, violent, cruel, and narrow-minded and are easily incited by their leaders. They are waiting for the Jews to leave their land. Al-Muqri's novel is an attempt to explain the many reasons behind the emotional excitement and the persistent feeling of longing that are awakened among the Jews: first, the already existing messianic expectations; second, the oppression and suffering of the Jews and finally, their exile to the unknown region called Mawza. All these drove Jews to immigrate to Israel as soon as they had the opportunity to do so. Al-Muqri is trying to find a vindication or justification for the flight of Yemenite Jews to Israel. 
The novel discusses religious intolerance. Al-Muqri is not against religion. He is against the misuse of religion. He is against religious fanaticism and extremism. He is of the opinion that the persecution of Jews throughout history is due to religion. Before re-narrating the chronicles of Yemenite Jews, Al-Muqri in the first half of the novel tries to establish the idea that religion is at the root of what happened to Yemenite Jews. Al-Muqri questions the strict and blind adherence to any religious doctrine and encourages religious freedom and the right to choose or change a religion. Further, he presents both religions on an equitable basis regarding their merits or demerits. Al-Muqri seems to be open-minded on the question of religious beliefs and affiliations.

It seems that Al-Muqri believes in the young generation. They are more openminded, tolerant and peaceful than their old counterparts. A generation that will tolerate religious affiliations, social classes and racial differences. The relation between the two lovers is marked by inequality. Fatima belongs to a rich family. She is the daughter of a jurist who interprets Muslim religious law, the highest position in the religious ladder. Salem belongs to a poor Jewish family, considered as an outsider by the society. He is religiously, socially, and racially different. But this does not stop Fatima from loving him. So, Al-Muqri makes characters of different religious and ethnic backgrounds communicate and develop a variety of interlocking relationships between the Jews and the Zaydis, the most important of which is the love relationship that develops between Fatima and Salem. This underlines the core theme of Al-Muqri's novel which is the possibility of friendship and love between two persons, if not two peoples, who are politically, ideologically, and religiously different.

Fatima and Salem are banished by both communities. They are banished because they transgress the narrow thinking of their communities. They are doomed because they fall in love though they are different. They are banished because they are able to overcome the hostilities of the two religions, and the ideology of the two communities. They reject fundamentalism, fanaticism and religious barriers between humans. Fatima and Salem have crossed the religious barrier and the dividing line. However, their cross is a passage to freedom. They have managed to escape from religious restrictions and communal conflicts. Their crossing of the barrier takes both physical and conceptual dimensions. It is a crossing of the geographical borders (i.e., from Raydah to Sana'a) and of moral or psychological borders (when they develop a romantic relationship with each other).

Finally, Ali Al-Muqri provides a narrative deploying positive Jewish images and foregrounding the human dimensions of the Jew as a victim of a history of persecution and genocide and challenging the conservative Arabic discourse and therefore paving the way for a new age of sympathetic Jewish images in Arabic fiction. He attempts to be objective in his treatment of the Jew as a historical victim. Hence Al-Muqri is one of the first writers who started the process of humanization of the Jewish subject through fiction in the new millennium. 
Address:

Ebrahim Mohammed Alwuraafi

Department of English Language and Literature

Faculty of science and Art-Al-Mandaq

Al-Baha University

Kingdom of Saudi Arabia

E-mails: ebrahimwarafi@gmail.com,e.mohammed@bu.edu.sa

\section{References}

Abu Jabal, Kamilia (1999) Yahud Al-Yemen: dirasa siyasiyah, iqtisadia and ijtima'eya. [Yemenite Jews: a political, economic and social study.] Damascus, Syria: Dar Alnumair Publishering House.

Al-Ameri, Suzan (2011) “Al-Yahudi Al-Hali: qisat hob tatakhata al-ikhtilaf ad-deni”. [The Handsome Jew: a love story that transcends religious difference.] Al-Emarat Al-Youm. Available online at $<$ https://www.emaratalyoum.com/life/culture/2011-11-21-1.438832>. Accessed on January 26, 2026.

Al-Hasan, Abdullatif A. (2014) Athar alfikr Alyahudi ala ghalat Ashi'a. [The impact of Jewish thought on the Shi'ites.] Riyadh, KSA: Obekan Publishing.

Al-Muqri, Ali (2011) Al-Yahudi Al-Hali. [The Handsome Jew.] Beirut, Lebanon: Dar Al-Saqi.

Al-Shuga'a, Abdul Rahman A. (2013) Tarikh al-Yemen fi al-Islam. [History of Yemen in Islam.] 8th ed. Sana'a, Yemen: Al-Ihsan Net.

Arendt, Hannah (1970) On violence. New York, NY: A Harvest/HBJ Book.

Ariel, Ari (2014) Jewish-Muslim relations and migration from Yemen to Palestine in the late nineteenth and twentieth centuries. Leiden, The Netherlands: Brill.

Blady, Ken (2000) Jewish communities in exotic places. Jerusalem, Israel: Jason Aronson Inc.

Klorman, B. Z. Eraqi (1993) The Jews of Yemen in the nineteenth century: a portrait of a messianic community. New York, NY: E.J. Brill.

Klorman, B. Z. Eraqi (2002) "Yemen". In Reeva Spector Simon, Michael Menachem Laskier, and Sara Reguer, eds. The Jews of the Middle East and North Africa in modern times, 389-408. New York, NY: Columbia University Press.

Klorman, B. Z. Eraqi (2014) Traditional society in transition: the Yemeni Jewish experience. Leiden, The Netherlands: Brill.

Maimonides, Moses (1993) Epistles of Maimonides: crisis and leadership. Abraham S. Halkin, transl. Philadelphia, PA: Jewish Publication Society.

McCord, Stephen K. (2018) "Yemen". In Encyclopedia of Christianity in the Global South. Vol. 2, 865-867. New York, NY: The Roman \& Littlefield Publishing Group, Inc.

Parfitt, Tudor (1996). The road to redemption: The Jews of the Yemen 1900-1950. Leiden, The Netherlands: E J Brill.

Quran 27:44. Available online at $<$ https://quran.com/27/1-93>. Accessed on January 26, 2020.

Saleh, Hadi Mohammed (2016) Asifat al-hazm. [Decisive storm.] Al-Janadria, KSA: Al-Janadria Publishing.

Sartre, Jean-Paul (1963) "Preface". In Frantz Fanon, ed. The wretched of the earth, 7-35. Constance Farrington, transl. New York, NY: Grove Press. 
Tawil, Hayim (1998) Operation Esther: opening the door for the last Jews of Yemen. New York, NY: Belkis Press.

Tobi, Yosef (1999) The Jews of Yemen: studies in their history and culture. Leiden, The Netherlands: Brill.

Tobi, Yosef (2013) "Jews of Yemen". In Abdelwahab Meddeb and Benjamin Stora, eds. A history of Jewish-Muslim relations from the origins to the present day, 248-257. Princeton: Princeton University Press. 